\title{
Abundance, distribution and feeding patterns of a temperate reef fish in subtidal environments of the Chilean coast: the importance of understory algal turf
}

\author{
Abundancia, distribución y patrones alimentarios de un pez de arrecifes templados en \\ ambientes submareales de la costa de Chile: la importancia de la capa \\ de algas del subdosel
}

\section{ÁLVARO T. PALMA ${ }^{1} \&$ F. PATRICIO OJEDA ${ }^{2}$}

${ }^{1}$ Facultad de Ciencias, Universidad Católica de la Santísima Concepción, Casilla 297, Concepción, Chile

${ }^{2}$ Departamento de Ecología, Facultad de Ciencias Biológicas, Pontificia Universidad Católica de Chile, Casilla 114-D, Santiago, Chile

${ }^{3}$ Centro de Estudios Avanzados en Ecología \& Biodiversidad

${ }^{1}$ Corresponding author: e-mail: apalma@ucsc.cl

\begin{abstract}
Cheilodactylus variegatus is an abundant carnivorous demersal reef fish that lives in the shallow subtidal of the northcentral Chilean coast. Characteristically, these environments are dominated by kelp forests of Lessonia trabeculata. This species preys on a great variety of benthic invertebrates, and shows particularly high consumption rates on amphipod crustaceans. In our study, two widely separated populations of $C$. variegatus were considered (central and northern Chile). Individuals that form part of these populations show considerable differences in their distribution, abundance and trophic behavior. In the northern zone, the species is abundant and both juveniles and adults are distributed along the whole bathymetric gradient. This contrasts with populations found in central Chile, which are more sparse and lack juveniles. The distribution and abundance patterns appear to be influenced mainly by the great abundance of diverse understory macroalgae in the northern subtidal, which harbors a large number of invertebrates, especially amphipods. In contrast, the understory algal abundance of the central zone is much lower, and does not show a direct relationship with the lesser abundance of amphipods. In general, $C$. variegatus maintains a high consumption rate on amphipods throughout its ontogeny but it includes several other prey items in later ontogenetic stages. The different understory algal assemblages, and their associated fauna, are likely to be the main factors influencing the patterns of abundance and distribution observed between these two geographically distinct fish populations.
\end{abstract}

Key words: Cheilodactylidae, shallow subtidal, understory macroalgae, carnivorous fish, amphipods, distribution, abundance, Chile.

\section{RESUMEN}

Cheilodactylus variegatus es un pez demersal abundante que habita el submareal somero de la costa norte y central de Chile. Es característico de estos ambientes el estar dominados por praderas del alga Lessonia trabeculata. Esta especie incorpora en su dieta una variada gama de invertebrados bentónicos, mostrando una tasa particularmente alta de consumo de crustáceos anfípodos. En nuestro estudio, se consideró dos poblaciones ampliamente separadas de $C$. variegatus (centro y norte de Chile). Los individuos que integran estas poblaciones exhiben claras diferencias en su distribución, abundancia y comportamiento trófico. En la zona norte, la especie es abundante y tanto juveniles como adultos se distribuyen a lo largo de todo el gradiente batimétrico. Esto contrasta con las poblaciones de la zona central de Chile, las que están más dispersas y desprovistas de juveniles. El patrón de distribución y abundancia parece estar principalmente influenciado por la gran abundancia de diversas especies de macroalgas que conforman el subdosel en el submareal del norte, el que es habitado por un gran número de invertebrados, especialmente anfípodos. En contraste, la abundancia de algas del subdosel de la zona central es mucho menor y no muestra una relación directa con la menor abundancia de anfípodos observada. La tasa de consumo que $C$. variegatus ejerce sobre anfípodos es en general alta durante toda su ontogenia, incorporando a otros ítems presa en estadíos ontogenéticos posteriores. Es posible que los diferentes ensambles de diversas algas de subdosel, junto con su fauna asociada, sean el principal factor que afecta los patrones de abundancia y distribución observado entre estas dos poblaciones de peces geograficamente distintas.

Palabras clave: Cheilodactylidae, submareal somero, algas de la capa del subdosel, pez carnívoro, anfípodos, distribución, abundancia, Chile. 


\section{INTRODUCTION}

Several factors have been documented that explain the patterns of distribution and abundance of littoral marine fish (Choat 1982, Choat \& Ayling 1987). Among others, substratum heterogeneity has been indicated frequently as playing an important role affecting both diversity and abundance of reef fish assemblages (Luckhurst \& Luckhurst 1978a, 1978b, Sedberry \& Van Dolah 1984, Richards 1986, Choat \& Bellwood 1991, Ebeling \& Hixon 1991). In rocky subtidal habitats, the presence of macroalgal beds markedly increases substratum complexity, adding a threedimensional component to the environment (Stoner \& Livingston 1980, Larson \& De Martini 1984).

It has frequently been shown that the presence of macroalgae, particularly kelp beds, affects the distribution and abundance of littoral marine fish (Moreno et al. 1979, Choat 1982, Bodkin 1988, Anderson 1994). Macroalgae may serve as refuge from predators (Werner et al. 1983, Larson \& De Martini 1984, Carr 1989, De Martini \& Roberts 1990, Gotceitas 1990a, 1990b) or as grazing habitats (Holbrook \& Schmitt 1984, 1989, Moreno \& Jara 1984, De Martini \& Roberts 1990, Gotceitas 1990a, 1990b, Hay et al. 1990). Most of these studies, however, have focussed on assessing the ecological importance of large brown algae (i.e., kelp), paying little attention to the potential role that understory algae might have on the structure and abundance of temperate reef fish assemblages (Angel \& Ojeda 2001). At such scale, understory algae provide multiple opportunities for microhabitat utilization by fishes (e.g., refugia and habitat for preys).

Cheilodactylus variegatus (Valenciennes 1833) is a common carnivorous reef fish inhabiting rocky subtidal habitats along the northern and central coast of Chile (Miranda 1967, Moreno et al. 1979, Soto 1985). It ranges from Paita $\left(05^{\circ} 04^{\prime} \mathrm{S}, 81^{\circ}\right.$ $\left.05^{\prime} \mathrm{W}\right)$, Perú to Metri bay (41 $\left.{ }^{\circ} 36^{\prime} \mathrm{S}, 7^{\circ} 43^{\prime} \mathrm{W}\right)$, Chile (Chirichigno 1974, Vargas \& Pequeño 2001). Despite being reported as one of the most abundant nearshore fishes along this range (Miranda 1967), little quantitative information has been gathered on basic aspects of its biology and ecology. Nielsen (1963) reported post-larval stages of this species in open waters off the coast of Perú and northern Chile. More recently, Soto (1985) and Núñez \& Vásquez (1987) documented that adult populations of $C$. variegatus are closely associated with the brown kelp Lessonia trabeculata, preying upon a large suite of invertebrates. Other basic natural history aspects of this organism, particularly those related to juvenile stages, remain unknown.
The aims of the present study were: (1) to determine the patterns of abundance and distribution of Cheilodactylus variegatus, (2) to provide a detailed description of its natural diet throughout its ontogeny, and (3) to assess the importance of kelp and understory beds in affecting the spatial distribution and trophic behavior of this species.

This study was conducted on a broad geographical scale, which included two study sites within two zones that strongly differ in diversity and abundance of benthic macroalgae (Camus \& Ojeda 1992, Cáceres et al. 1994).

\section{MATERIAL AND METHODS}

Study sites

This study was conducted in the rocky subtidal zone at four sites on the Chilean coast: Caleta Errázuriz $\left(23^{\circ} 29^{\prime} \mathrm{S}, 70^{\circ} 38^{\prime} \mathrm{W}\right)$ and Isla Santa María ( $\left.23^{\circ} 27^{\prime} \mathrm{S}, 70^{\circ} 38^{\prime} \mathrm{W}\right)$ in the north of Chile in the vicinity of Antofagasta (Tropic of Capricorn), and Punta de Tralca $\left(33^{\circ} 35^{\prime} \mathrm{S}, 71^{\circ} 42^{\prime} \mathrm{W}\right.$ ) and Quintay (33 $\left.11^{\prime} \mathrm{S}, 71^{\circ} 43^{\prime} \mathrm{W}\right)$ in central Chile near Valparaíso (Fig. 1). The substratum of

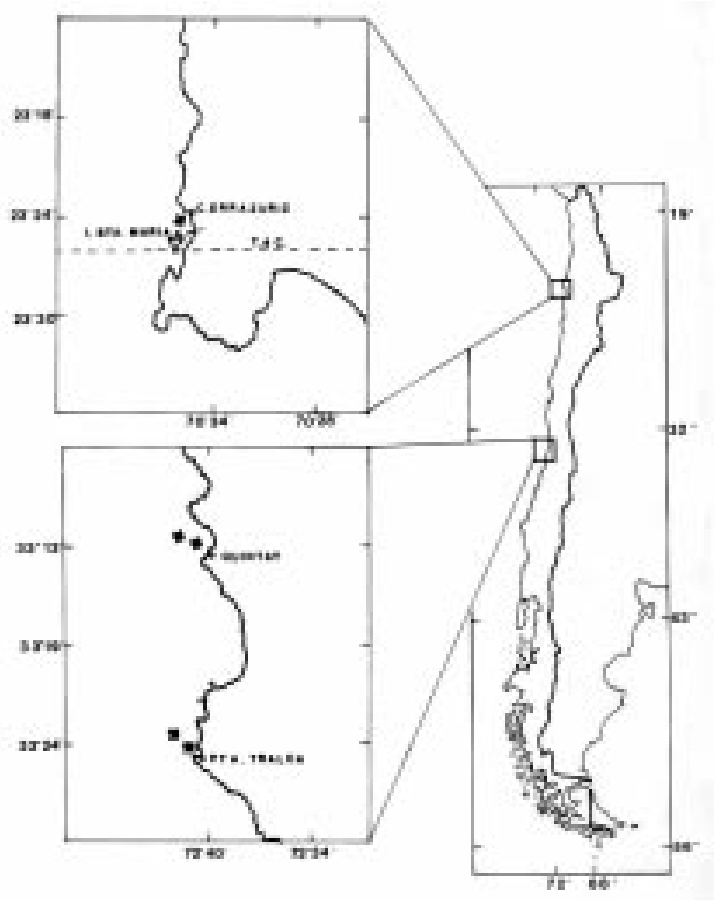

Fig 1: Location of the study sites of the northern and central coast of Chile.

Ubicación de los sitios de estudio en la costa norte y centro de Chile. 
the subtidal zone in all these sites is similar and consists of a sloping bedrock with large ledges and boulders in the shallower portions, $(0-6 \mathrm{~m}$ depth), and with increasing proportions of sand in the deeper portions (6-18 m depth). Large plants of the brown kelp, Lessonia trabeculata, form an extensive bed extending from 3 to $12 \mathrm{~m}$ below MLWL, although less abundant, individual plants grow at depths of $16-18 \mathrm{~m}$. There are marked differences however, in the understory algal assemblages between the northern sites and the central ones. The understory in Caleta Errázuriz and Isla Santa María (hereafter referred as Northern Zone = NZ) consists of a suite of species dominated by Ulva spp., Halopteris hordacea, Asparagopsis spp, Chondria spp. and Chondrus spp. (Cáceres et al. 1993). In contrast, the understory algal community in Punta de Tralca and Quintay (hereafter referred as Central Zone $=\mathrm{CZ}$ ) is conspicuously poor both in abundance and species diversity, with small isolated patches of Glossophora kunthii and Gelidium spp.

\section{Samplings}

Identical seasonal samplings were performed for fish and for the benthic flora and fauna at the four sites. In NZ, samplings were conducted in May, August and November 1989, and in January, June, September and November 1990. In CZ, they were carried out in May, September and November 1989 and in January, June and August 1990.

Fish were sampled for 3 days and 3 nights using three 3 x 50 m experimental gillnets consisting of five panels (graded in mesh size from 10 to 50 $\mathrm{mm}$ ) that were randomly set along the bottom, perpendicular to the coastline at depths between 5 and $18 \mathrm{~m}$. The gillnets were set within the first hour after sunrise and retrieved one hour before sunset. All captured specimens were measured (standard length $=$ SL, and maxillary length $=$ ML) to the nearest millimeter, and weighed to the nearest $1.0 \mathrm{~g}$. Their stomachs, intestines, and gonads were removed and fixed in a 5 to $10 \%$ solution of buffered formalin in seawater, placed in labeled plastic bags, and transported to the laboratory for further analysis.

The diet of $C$. variegatus was estimated from gut contents and identified to the finest taxonomic resolution, counted, measured to the nearest millimeter, and wet-weighed to the nearest milligram. The importance of each prey species was evaluated by calculating an index of relative importance IRI (Pinkas et al. 1971), as follows: IRI $=(\mathrm{N}+\mathrm{W}) \mathrm{FO}$, where $\mathrm{N}=$ percentage of numerical composition, $\mathrm{W}=$ percentage of gravi- metric composition, and $\mathrm{FO}=$ frequency of occurrence as percentage.

The abundance patterns of $C$. variegatus were determined by using a catch-per-unit-effort (CPUE) measurement (Ojeda \& Dearborn 1990) and compared by means of one factor ANOVA.

To estimate prey availability, we analyzed the distribution and abundance of benthic macroalgae and invertebrates from replicate $0.25 \mathrm{~m}^{2}$ quadrants, which were randomly sampled by SCUBA (Pringle 1984) at four different depths (3, 5, 7, and $9 \mathrm{~m}$ ). Fifty-six quadrats were sampled in the NZ and 50 quadrants were sampled in the CZ. All macroinvertebrates and algae found within the quadrats were removed from the substratum with the aid of scraping knives. Organisms were either manually collected and deposited in sampling bags of $1 \mathrm{~mm}$ mesh size or vacuumed with an airlift device (Palma et al. 1998). All sampled organisms were placed in labeled plastic bags, fixed in 5 to $10 \%$ of seawater formalin solution and transported to the laboratory for analysis.

Although $C$. variegatus is a benthic feeder, personal field observations show that it preferentially harvests invertebrate prey from certain benthic algae, Halopteris hordacea and Asparagopsis spp. in the NZ and Glossophora kunthii in the CZ. Prey on these algal species were sampled by placing a plastic bag over each plant underwater. The samples were preserved in $10 \%$ seawater formalin solution. Invertebrates were removed from the algal samples in the laboratory by vigorous washing, then counted and identified. Association between amphipods and the algae were analyzed in terms of number and dry biomass of amphipods per dry algal biomass.

To determine the spatial distribution and abundance of fish as well as substratum type along the bathymetric gradient, visual underwater censuses were conducted during the day time using SCUBA. A total of 32 and 49 transects extending across the kelp bed were made from 0 to $10 \mathrm{~m}$ below MLWL in the $\mathrm{NZ}$ and the $\mathrm{CZ}$, respectively. Each transect was $4 \mathrm{~m}$ wide. Transects were surveyed in segments covering $2 \mathrm{~m}$ depth intervals. The total surface covered by every $2 \mathrm{~m}$ depth interval was a function of the slope of the bottom which was calculated by placing a line perpendicular to the coast line going from the shallowest to the deepest part of the area surveyed. Two divers independently searched each of these areas exhaustively, recording the number of adults and juvenile specimens of $C$. variegatus. Based on gonad differentiation, fish less than $170 \pm 15 \mathrm{~mm} \mathrm{SL}(80 \pm 5 \mathrm{~g})$ were designated as juveniles. A G-test analysis of $2 \times 2$ contingency tables was used to determine whether the spatial distribution of $C$. variegatus 
was significantly associated with L. trabeculata forests.

The bathymetric distribution of $C$. variegatus in the $\mathrm{C}$. $\mathrm{Z}$ was analyzed by a one factor ANOVA and by a two factor ANOVA in the NZ. In either case, data of abundance by depth were analyzed using the F-max test of variance homogeneity (Sokal \& Rohlf 1981). The results of this test showed lack of homogeneity in the bathymetric gradient, therefore a logarithmic transformation was used (ln [1+X]; Sokal \& Rohlf 1981). A one factor ANOVA was also used to study the pattern of algal abundance along the bathymetric gradient.

The association between algal biomass and amphipods by depth and the seasonal variation of prey (invertebrates) availability and diet were analyzed using non-parametric statistics. In the first case, the Kendall rank-order correlation test was used to determine measurements of association; in the second case the Kolmogorov-Smirnov two sample test was applied for goodness of fit (Siegel \& Castellan 1988).

Pearre's "C" selectivity coefficient (Pearre 1982) was used to estimate preferences in diet of the eight most abundant prey (by biomass). Selectivity was compared for each prey in relation to the remaining taxa available in the environment that were also present in the diet of $C$. variegatus.

Relationships between the largest prey found in each gut, expressed in $\mathrm{mg}$, and the importance in biomass of amphipods in the diet during ontogeny, standardized by the size of each fish, were compared by simple regression analyses. In both cases a transformation $(\ln [1+\mathrm{x}])$ to the size of the largest prey $(\mathrm{mg})$ and to the ratio between amphipod biomass (mg) and fish size (g) was performed to make those factors linear in relation to the fish size in grams. Both independent variables were log-normally distributed, and therefore a logarithmic transformation was appropriate to normalize the data. The diversity of the diet in each zone was estimated by applying the Shannon diversity index (H) (Zar 1999). Significance level was set at $\alpha=0.05$ in all parametric statistical analyses.

\section{RESULTS}

\section{Abundance and spatial distribution}

A total of 240 specimens ranging in size from 93 to $350 \mathrm{~mm}$ in SL were captured in the NZ and 55 individuals ranging from 170 to $390 \mathrm{~mm}$ in the CZ. No significant differences in abundance patterns of C. variegatus were detected between the two sites within each zone (one factor ANOVA, $\mathrm{NZ}: \mathrm{F}=0.234, \mathrm{P}=0.630, \mathrm{CZ}: \mathrm{F}=0.180, \mathrm{P}=$ 0.673).

The presence of numerous juveniles in the populations of the NZ (56 individuals), resulted in a smaller mean size for the NZ population (mean body weight $\pm 1 \mathrm{SD}, \mathrm{NZ}=233 \pm 55 \mathrm{~g}, \mathrm{CZ}=752 \pm$ $101 \mathrm{~g}$, one-way ANOVA, F = 147.84, P < 0.0001 ). The mean body weight for individuals with developed gonads (adults) also differed significantly between zones $(\mathrm{NZ}=283 \pm 61 \mathrm{~g}( \pm 1 \mathrm{SD}), \mathrm{CZ}=$ $662 \pm 88 \mathrm{~g}( \pm 1 \mathrm{SD})$, one-way ANOVA, F = 72.73, $\mathrm{P}<0.01)$. Accordingly, the data from the northern zone and the central zone were treated independently for further analyses.

The bathymetric distribution of C. variegatus in both zones was closely associated with the pattern of spatial distribution of Lessonia trabeculata (G-test, $\mathrm{G}=131.85$, d.f. $=1, \mathrm{P}<$ $0.001)$. At both zones, C. variegatus was mainly distributed between 0 and $10 \mathrm{~m}$ depth (Fig. 2A, 2B). Cheilodactylus variegatus was rarely seen below $10 \mathrm{~m}$ depth (personal observation). This coincides with the maximum depth reached by the beds of L. trabeculata in both zones, and individuals were rarely seen swimming outside the kelp beds.

When comparing the bathymetric distribution of this species within the NZ, a significant increase in the number of individuals was detected with depth for juveniles ( $\mathrm{SL}<170 \mathrm{~mm}$ ) and adults (two-way ANOVA, F $=6.547, \mathrm{P}=0.0002$, see Fig. 2A). This trend was also present but not significant in the populations of the $\mathrm{CZ}$ where the complete absence of juveniles in the subtidal was conspicuous (Fig. 2B). Moreover, a homogeneous distribution pattern was evident in the NZ among juveniles and adults at the different depths, as there was no significant interaction between age class and depth (two-way ANOVA, F $=0.489, \mathrm{P}$ $=0.487$, Fig. 2A).

\section{Characteristics of the habitat}

Lessonia trabeculata is common on rocky bottoms throughout its range, but morphological differences exist between plants of these two regions. In the NZ these kelp beds are formed by highly branched, short plants, contrasting with the less branched and taller plants found in the CZ (Camus \& Ojeda 1992). Although both systems are dominated by L. trabeculata, 30 other algal species were found in the NZ and only 15 species in the $\mathrm{CZ}$ along the bathymetric gradient. Biomass of algae was constant over the depth range examined within each zone and one order of mag- 
(A) Northern Zone

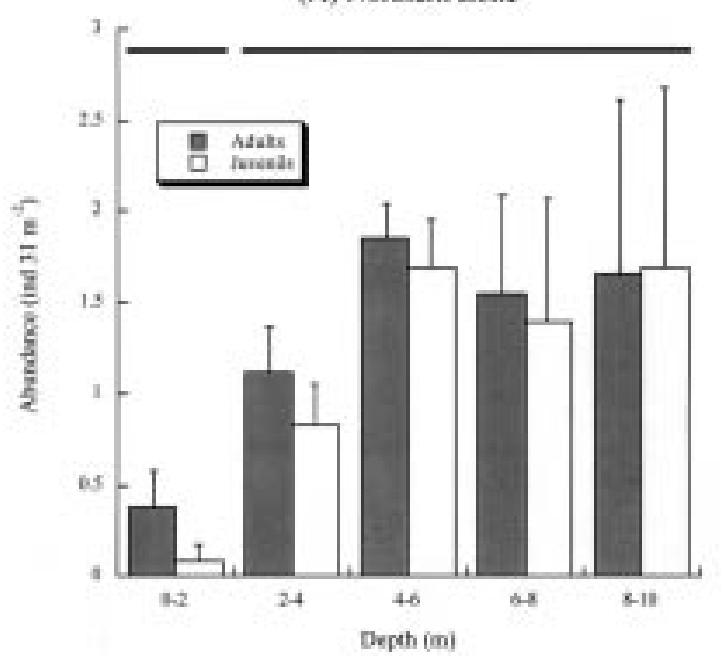

(B) Southern Zone

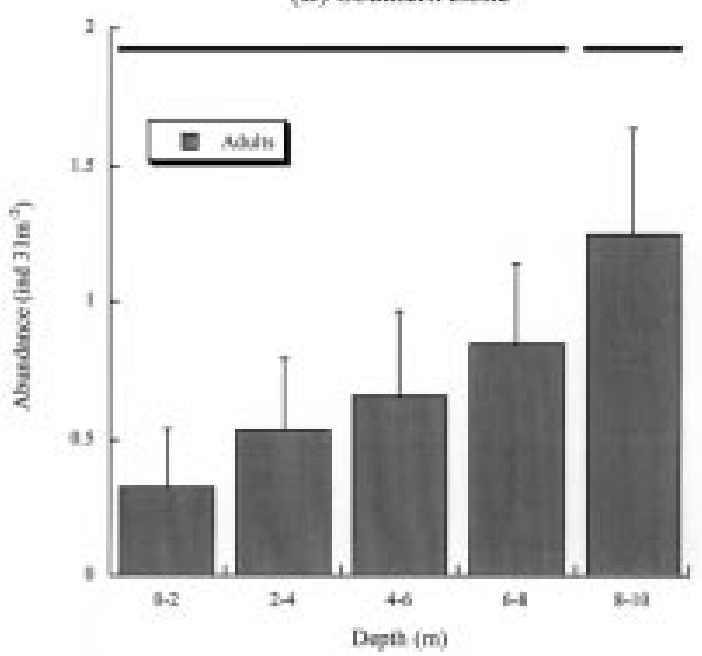

Fig. 2: Abundance of Cheilodactylus variegatus in each of five depth zones of: (A) the northern (NZ) and (B) central (CZ) zones. Fish abundance is the number of individuals ( \pm 1 SD) at each depth interval. Data were $(\ln [1+\mathrm{x}])$ transformed for ANOVA. Interrupted lines represent significant differences at $\mathrm{P}<0.05$.

Abundancia de Cheilodactylus variegatus en cada una de cinco zonas de profundidad en la zona: (A) norte (NZ) y (B) centro $(\mathrm{CZ})$. La abundancia de peces se expresa como el número de individuos $( \pm 1 \mathrm{DE})$ en cada intervalo de profundidad. Los datos fueron transformados $(\ln [1+\mathrm{x}])$ para el ANOVA. Líneas interrumpidas significan diferencias a P < 0,05 .

nitude higher in the NZ (one-way ANOVA, NZ: F $=0.191, \mathrm{P}=0.902, \mathrm{CZ}: \mathrm{F}=0.268, \mathrm{P}=0.848$, Fig. 3).

Of the remaining algal species (other than $L$. trabeculata) the following represent over $80 \%$ of the algal biomass in each zone; NZ: Ulva spp., Asparagopsis spp., Halopteris hordacea and Chondrus spp., CZ: Glossophora kunthii. and Gelidium spp.

Trophic behavior and variation of the diet in relation to body size

Gut contents were analyzed in 120 out of 240 individuals captured in the NZ and only 10 (8.7 $\%)$ were found empty. In the CZ $3(5.5 \%)$ of the gut contents of the 55 individuals captured were empty.

Cheilodactylus variegatus appeared to be a generalist carnivore preying on a variety of benthic invertebrates. When considering together the gut contents of both zones, 80 prey items were identified. Of these, only 28 accounted for greater than $1 \%$ of consumed biomass. Together these taxa accounted for $89 \%$ in weight of the total gut contents analyzed (Table 1). The greatest importance in weight was due to several amphipod crustaceans $(47 \%)$ and decapod crustaceans (13 $\%)$. The former were numerically most important $(72 \%)$. When grouped in higher taxa the IRI was highest for amphipods in both zones $(12,706$ ind in $\mathrm{NZ}$ and 8,202 ind in CZ). The remaining prey showed similar levels of importance in both zones (Table 2).

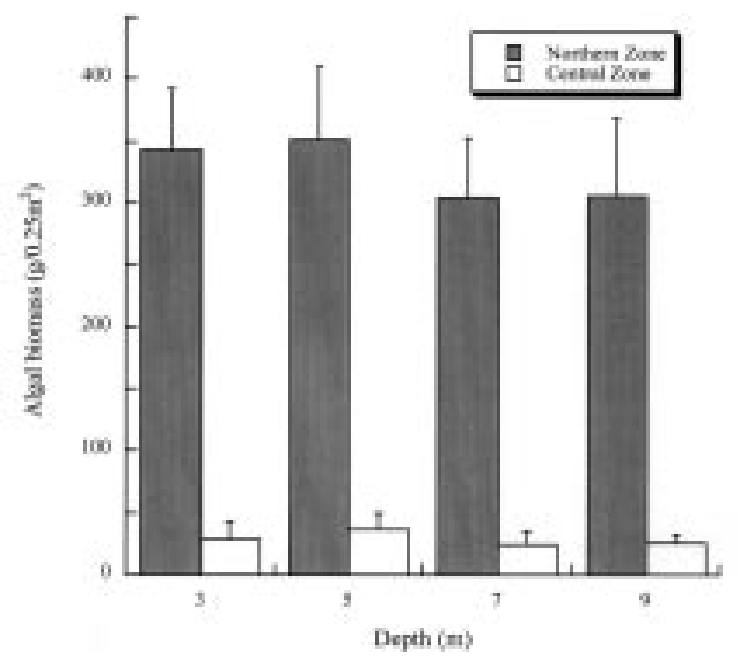

Fig. 3: Abundance of the total different algae (excluding Lessonia) present at each of four depths at the northern and central zones. Algal abundance is the mean biomass $( \pm 1 \mathrm{SE})$ at each depth.

Abundancia del total de distintas algas (excluyendo a Lessonia) presentes a cada una de cuatro profundidades en las zonas norte y central. La abundancia de algas es la biomasa promedio ( $\pm 1 \mathrm{EE})$ a cada profundidad. 
The density of amphipods in benthic algae was determined for three species (Table 3). Only in the NZ was there a close association between amphipod and algal biomass at all depths considered (Kendall partial rank-order correlation coefficient, NZ: $\mathrm{T}=0.283, \mathrm{P}<0.01, \mathrm{CZ}: \mathrm{T}=0.135$, $\mathrm{P}=0.21)$.

Selectivity of prey was minimal in both localities (Table 4). In the NZ the only selectivity was negative for gastropods. In the $\mathrm{CZ}$ amphipods, isopods and polyplacophora were positively selected and gastropods were negatively selected.

When considering only amphipods there was no pattern in their consumption with fish size in the NZ (NZ: $\left.\mathrm{r}^{2}=0.019, \mathrm{~F}=2.124, \mathrm{P}=0.148\right)$ (Fig. $4 \mathrm{~A})$, but in the CZ small fish consumed proportionally more amphipods than larger fish $\left(\mathrm{CZ}: \mathrm{r}^{2}=\right.$ $0.142, \mathrm{~F}=4.128, \mathrm{P}=0.05$ ) (Fig. 4B).

Larger $C$. variegatus consumed larger prey in the NZ $\left(r^{2}=0.34, F=54.4, P<0.0001\right)$ (Fig. 5A),

TABLE 1

The 28 most important prey items (> $1 \%$ in biomass of gut contents) from 80 that were found in 147 stomach analyzed. This represents the combined gut contents of the NZ and CZ.

Proportion in biomass $(\mathrm{PB})$ and number $(\mathrm{PN})$ is given; $\left(_{*}\right)=$ less than 0.01

Veinte y ocho de las presas más importantes ( $>1 \%$ de la biomasa del contenido gástricos) de las 80 que fueron encontradas en los 147 estómagos analizados. Se presentan los resultados combinados de los contenidos de NZ y CZ. Proporción de la biomasa (PB) y del número $(\mathrm{PN})$ total de presas; $\left.{ }_{*}\right)=$ menor que 0,01

\begin{tabular}{|c|c|c|}
\hline Prey item & $\mathrm{PB}$ & $\mathrm{PN}$ \\
\hline \multicolumn{3}{|l|}{ Polychaeta } \\
\hline \multicolumn{3}{|l|}{ Sabellariidae } \\
\hline Phragmatopoma sp. & 0.02 & $*$ \\
\hline Nereididae & 0.01 & * \\
\hline Lumbrineridae & 0.01 & $*$ \\
\hline \multicolumn{3}{|l|}{ Mollusca } \\
\hline \multicolumn{3}{|l|}{ Polyplacophora } \\
\hline Chiton cumingsii Frembley & 0.01 & $*$ \\
\hline Chaetopleura sp. & 0.01 & * \\
\hline Tonicia sp. & 0.06 & $*$ \\
\hline \multicolumn{3}{|l|}{ Gastropoda } \\
\hline Eatonina sp. & 0.03 & 0.07 \\
\hline Eatoniella sp. & 0.01 & 0.04 \\
\hline Fisurella maxima Sowerby & 0.01 & $*$ \\
\hline Fisurella cumingsi Reeve & 0.01 & $*$ \\
\hline Fisurella costata Lesson & 0.01 & $*$ \\
\hline \multicolumn{3}{|l|}{ Bivalvia } \\
\hline Entodesma sp. & 0.07 & 0.01 \\
\hline \multicolumn{3}{|l|}{ Crustacea } \\
\hline Branchiopoda & 0.01 & 0.06 \\
\hline \multicolumn{3}{|l|}{ Decapoda } \\
\hline Cancer setosus Molina & 0.01 & $*$ \\
\hline Pilumnoides perlatus (Poeppig) & 0.04 & 0.01 \\
\hline Allopetrolisthes angulosus (Guerin) & 0.01 & $*$ \\
\hline Pisoides edwardsi (Bell) & 0.03 & * \\
\hline Acanthonyx petiveri (H.Milne Edwards) & 0.01 & $*$ \\
\hline Synalpheus spinifrons (H.Milne Edwards) & 0.02 & $*$ \\
\hline Pagurus comptus White & 0.01 & $*$ \\
\hline \multicolumn{3}{|l|}{ Isopoda } \\
\hline Exosphaeroma gigas (Leach) & 0.01 & 0.02 \\
\hline \multicolumn{3}{|l|}{ Amphipoda } \\
\hline Gamaridea & 0.46 & 0.69 \\
\hline Caprellidea & 0.01 & 0.03 \\
\hline \multicolumn{3}{|l|}{ Echinodermata } \\
\hline \multicolumn{3}{|l|}{ Echinoidea } \\
\hline Tetrapygus niger (Molina) & 0.01 & $*$ \\
\hline Total & $251(\mathrm{~g})$ & 30,988 (ind) \\
\hline
\end{tabular}


but not in the $\mathrm{CZ}\left(\mathrm{r}^{2}=0.09, \mathrm{~F}=2.49, \mathrm{P}=0.128\right)$ (Fig. 5B). This is not surprising since there is a positive correlation between body size ( $\mathrm{g}$ ) and mouth size (maxillary length) for this species $(\mathrm{r}$ $=0.90, \mathrm{P}<0.001)$.

\section{DISCUSSION}

The geographic range of this study provided the possibility of studying populations of Cheilodactylus variegatus under different envi-

TABLE 2

The importance of different species or OTU (other taxonomic units) ordered in higher taxa that conform the diet of Cheilodactylus variegatus. The index of relative importance (IRI) proposed by Pinkas et al. (1971) consider biomass (\%), number (\%) and frequency of occurrence $(\%)$ of each prey item

Importancia de diferentes especies o OUT (otras unidades taxonómicas) ordenadas en taxa mayores que conforman

la dieta de C. variegatus. El índice de importancia relativa (IRI) propuesto por Pinkas et al. (1971) considera la biomasa (\%), el número (\%) y la frecuencia de ocurrencia (\%) de cada ítem de presa

\begin{tabular}{|c|c|c|c|c|c|c|c|c|}
\hline Prey taxa & Species or OTU & $\mathrm{n}$ & $(\%)$ & $\mathrm{FO}$ & $(\%)$ & W $(g)$ & $(\%)$ & IRI \\
\hline \multicolumn{9}{|l|}{ (A) Northern zone } \\
\hline Polychaeta & (3) & 11 & $(0.14)$ & 10 & $(19.61)$ & 5.37 & $(12.84)$ & 255 \\
\hline \multicolumn{9}{|l|}{ Mollusca } \\
\hline Polyplacophora & (1) & 1 & $(0.01)$ & 1 & $(1.90)$ & 0.02 & $(0.05)$ & 0 \\
\hline Gastropoda & (6) & 1,278 & $(16.40)$ & 29 & $(56.90)$ & 5.20 & $(12.40)$ & 1,636 \\
\hline Bivalvia & (2) & 42 & $(0.54)$ & 3 & $(5.88)$ & 0.20 & $(0.48)$ & 6 \\
\hline \multicolumn{9}{|l|}{ Arthropoda } \\
\hline \multicolumn{9}{|l|}{ Crustacea } \\
\hline Amphipoda & (6) & 5,968 & $(76.47)$ & 46 & $(90.20)$ & 26.93 & $(64.40)$ & 12,706 \\
\hline Isopoda & (3) & 51 & $(0.65)$ & 14 & $(27.45)$ & 0.26 & $(0.62)$ & 35 \\
\hline Cumacea & (1) & 30 & $(0.38)$ & 2 & $(3.92)$ & 0.02 & $(0.05)$ & 2 \\
\hline Decapoda & (5) & 45 & $(0.58)$ & 25 & $(49.02)$ & 2.42 & $(5.79)$ & 312 \\
\hline Zoea Larvae & (1) & 32 & $(0.41)$ & 3 & $(5.88)$ & 0.03 & $(0.07)$ & 3 \\
\hline Megalopa Larvae & (1) & 11 & $(0.14)$ & 1 & $(1.96)$ & 0.08 & $(0.19)$ & 1 \\
\hline Branchiopoda & (1) & 323 & (4.14) & 13 & $(25.49)$ & 0.68 & (1.63) & 141 \\
\hline \multicolumn{9}{|l|}{ Echinodermata } \\
\hline Echinoidea & (1) & 4 & $(0.05)$ & 5 & $(9.80)$ & 0.17 & $(0.41)$ & 5 \\
\hline \multicolumn{9}{|l|}{ (B) Central zone } \\
\hline Nemertea & $(1)$ & 13 & $(0.28)$ & 3 & $(7.89)$ & 0.47 & $(0.50)$ & 4 \\
\hline Polychaeta & (10) & $(2.49)$ & 22 & $(57.89)$ & 5.37 & $(5.69)$ & 473 & 116 \\
\hline \multicolumn{9}{|l|}{ Mollusca } \\
\hline Polyplacophora & (4) & 51 & $(1.09)$ & 15 & $(39.47)$ & 11.64 & (12.34) & 530 \\
\hline Gastropoda & (14) & 136 & $(2.92)$ & 22 & $(57.89)$ & 8.88 & $(9.41)$ & 713 \\
\hline Bivalvia & (2) & 248 & $(5.32)$ & 20 & $(52.63)$ & 16.21 & $(17.18)$ & 1,184 \\
\hline \multicolumn{9}{|l|}{ Arthropoda } \\
\hline Inscta & (1) & 19 & $(0.41)$ & 10 & $(26.32)$ & 0.16 & $(0.17)$ & 15 \\
\hline \multicolumn{9}{|l|}{ Chelicerata } \\
\hline Pycnogonida & (1) & 1 & $(0.02)$ & 1 & $(2.63)$ & 0.10 & $(0.11)$ & 0 \\
\hline \multicolumn{9}{|l|}{ Crustacea } \\
\hline Amphipoda & (6) & 3,509 & $(75.32)$ & 29 & $(76.32)$ & 30.33 & $(32.15)$ & 8,202 \\
\hline Isopoda & (5) & 94 & $(2.02)$ & 17 & $(44.74)$ & 0.94 & $(1.00)$ & 135 \\
\hline Cumacea & (1) & 6 & $(0.13)$ & 3 & $(7.89)$ & 0.03 & $(0.03)$ & 1 \\
\hline Cirripedia & (2) & 24 & $(0.52)$ & 4 & $(10.53)$ & 0.22 & $(0.23)$ & 7 \\
\hline Decapoda & (13) & 428 & (9.19) & 28 & (73.68) & 19.44 & $(20.60)$ & 2,194 \\
\hline \multicolumn{9}{|l|}{ Echinodermata } \\
\hline Echinoidea & (2) & 14 & $(0.30)$ & 6 & (15.79) & 0.56 & $(0.59)$ & 14 \\
\hline
\end{tabular}


TABLE 3

Relationship between amphipod dry biomass $(\mathrm{mg})$ and the number of amphipods per $1 \mathrm{~g}$ dry algal biomass. Numbers are the average and standard deviation, respectively. Sample size is 12 plants in each case; Northern Zone (NZ) and Central Zone (CZ)

Relación entre la biomasa seca de anfípodos ( $\mathrm{mg}$ ) y el número de anfípodos por gramo seco de biomasa algal. Números corresponden al promedio y la desviación estándar, respectivamente. El tamaño muestral fue de 12 plantas en cada caso; Zona Norte (NZ) y Zona Central (CZ)

\begin{tabular}{lccc}
\hline Algal species & Amphipod biomass & Amphipod number & \\
\hline Halopteris sp. & $15.7 \pm 9.1$ & $46.2 \pm 20.8$ & $\mathrm{NZ}$ \\
Asparagopsis sp. & $20.1 \pm 8.7$ & $75.6 \pm 18.0$ & $\mathrm{NZ}$ \\
Glossophora sp. & $25.6 \pm 12.3$ & $59.0 \pm 25.1$ & $\mathrm{CZ}$ \\
\hline
\end{tabular}

ronmental conditions. One species distributed along a wide geographical range is likely to be exposed to different conditions that can be abiotic (e.g., temperature, salinity) or biotic (e.g., different community composition). The analysis of these results shows both similarities and differences for certain life history aspects such as population density, size frequency distribution and feeding habits.

Patterns of distribution, abundance and dietary (trophic) habits of this species were closely associated with its habitat (i.e., rocky bottoms dominated by extensive kelp beds). The negative or positive effect that kelp-dominated systems exert upon the abundance of different fish species in shallow subtidal environments has been widely documented for systems in the northern hemisphere (Dayton 1985a, 1985b, De Martini \& Roberts 1990, Holbrook et al. 1990). In contrast, little information is available for southern hemisphere temperate coasts where the subtidal is dominated by Lessonia trabeculata (Núñez \& Vásquez 1987, Camus \& Ojeda 1992). Although in this study we did not analyze in detail the type of mechanism that relates $C$. variegatus with the kelp beds, the close association observed shows a positive effect. It is quite rare to find C. variegatus inhabiting bottoms not covered by kelp (Núñez \& Vásquez 1987, and personal observations). Kelp also creates high productivity and structural complexity which could influence the observed patterns of algae-fish association (Moreno et al. 1979, Angel \& Ojeda 2001).

The diversity of foliose algae under the canopy of $L$. trabeculata is a conspicuous difference between these two zones. The greater diversity of species and the greater biomass in the NZ subtidal (Fig. 3) is important since, in association with these algae (particularly Halopteris sp. and Asparagopsis spp.) exists a great variety and abundance of invertebrates, mainly amphipods (Table.

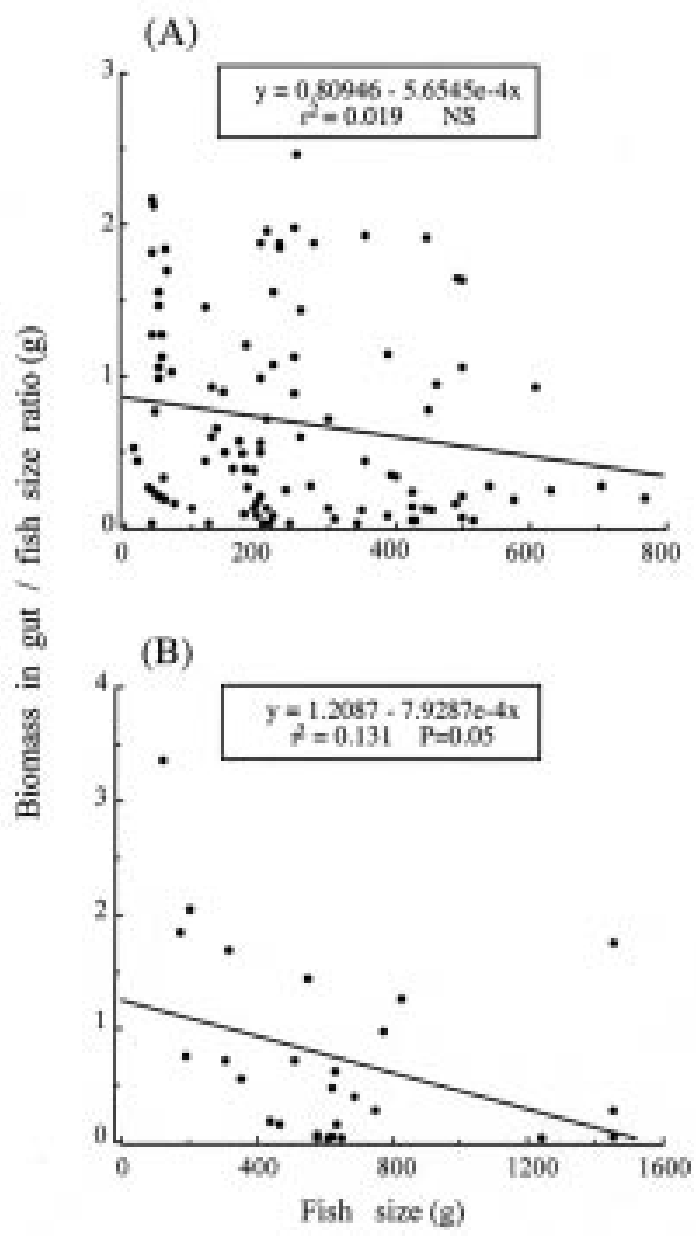

Fig. 4: The relationship between Cheilodactylus variegatus size $(\mathrm{g})$ and the ratio between amphipod biomass in the gut and fish size (ln [mg] + 1 transformed) in (A) NZ and (B) CZ; NS $=$ no significant differences.

La relación entre el tamaño de Cheilodactylus variegatus (g) y la razón entre la biomasa de anfípodos en los estómagos y el tamaño del pez (ln $[\mathrm{mg}]+1$ transformado) en (A) NZ y (B) $\mathrm{CZ}$; NS = no existen diferencias significativas. 
TABLE 4

Feeding preferences of Cheilodactylus variegatus in NZ and CZ Only the prey taxa contributing more than $2 \%$ by number or weight to the diet were included. Chi-square analysis (Pearre 1982) was used to evaluate the significance of taxon selection or avoidance;

$$
(+)=\text { selection },(-)=\text { avoidance }
$$

Preferencias alimentarias de $C$. variegatus en NZ y CZ Solo se incluyó aquellos taxa presa que contribuyeron con más del $2 \%$ en número y peso a la dieta. Se utilizó un análisis de chi-cuadrado (Pearre 1982) para evaluar la significancia de la selección o rechazo de cada taxón; $(+)=\operatorname{selección,~}(-)$ = rechazo

\begin{tabular}{|c|c|c|c|c|c|c|c|c|c|c|}
\hline \multirow[t]{2}{*}{ Prey resource } & \multicolumn{2}{|c|}{ Availability } & \multicolumn{2}{|c|}{$\begin{array}{c}\text { Diet } \\
\text { (biomass } \\
\text { proportion) }\end{array}$} & \multicolumn{2}{|c|}{$\begin{array}{c}\text { Electivity } \\
\text { (biomass } \\
\text { proportion) }\end{array}$} & \multicolumn{2}{|c|}{$\begin{array}{c}\mathrm{X}^{2} \text {-value } \\
\text { (Pearre } \\
\text { index "C") }\end{array}$} & \multicolumn{2}{|c|}{ Significance } \\
\hline & $\mathrm{NZ}$ & $\mathrm{CZ}$ & $\mathrm{NZ}$ & $\mathrm{CZ}$ & $\mathrm{NZ}$ & $\mathrm{CZ}$ & $\mathrm{NZ}$ & $\mathrm{CZ}$ & $\mathrm{NZ}$ & $\mathrm{CZ}$ \\
\hline Amphipoda & 0.683 & 0.017 & 0.533 & 0.399 & +0.073 & +0.455 & 5.035 & 183.853 & NS & $P<0.001$ \\
\hline Isopoda & 0.001 & 0 & 0.026 & 0.027 & +0.093 & +0.089 & 5.380 & 7.054 & NS & $\mathrm{P}=0.05$ \\
\hline Branchiopoda & 0 & - & 0.025 & - & +0.098 & - & 6.017 & - & NS & - \\
\hline Gastropoda & 0.546 & 0.576 & 0.109 & 0.057 & -0.270 & -0.241 & 45.378 & 51.744 & $P<0.001$ & $P<0.001$ \\
\hline Polychaeta & 0.055 & 0.108 & 0.097 & 0.138 & +0.045 & +0.015 & 1.230 & 0.209 & NS & NS \\
\hline Bivalvia & 0.026 & 0.066 & 0.008 & 0.037 & +0.021 & +0.019 & 0.286 & 0.318 & NS & NS \\
\hline Polyplacophora & 0.001 & 0.101 & 0 & 0.225 & +0.001 & +0.087 & 0.001 & 6.718 & NS & $P=0.05$ \\
\hline Decapoda & 0.201 & 0.100 & 0.162 & 0.119 & +0.025 & +0.001 & 0.397 & 0 & NS & NS \\
\hline
\end{tabular}

3). This kind of association is very common among other invertebrates and algae (Edgar 1983a, Hay et al. 1990), although the number of animals found may vary depending on the habitat architecture created by the algae (Hacker \& Steneck 1990). Algae such as Halopteris and Asparagopsis show the kind of heterogeneous spatial complexity that provides a suitable habitat for amphipods. Their morphology corresponds to the highly heterogeneous type of algae described in the literature (Hacker \& Steneck 1990). Abundance in phytal animals has shown strong correlation between algal density and the physical characteristics of their algal habitat (Mckenzie \& Moore 1981, Edgar 1983a, 1983b). It has been proposed that foliose understory algae are important refugia for fishes against predation (Stepien 1986). In our case, the biomass and especially the number of amphipods inhabiting Halopteris and Asparagopsis in the NZ (Table. 3) supports the idea that a large population of all sizes of $C$. variegatus consume amphipods as its main prey (Fig. 4A). In contrast, the algal species that supports important amounts of amphipods in the CZ is Glossophora kunthii. The biomass and number of amphipods in relation to this algae's biomass was of the same order of magnitude as those from the northern sites (see Table 3), however, the abundance of this algae along the bathymetric range is comparatively smaller, resulting in an average lower abundance of amphipods (Fig. 3, Table 3).

A second obvious difference between both zones is the lack of juveniles along the bathymetric range of the CZ. This pattern could partly be explained

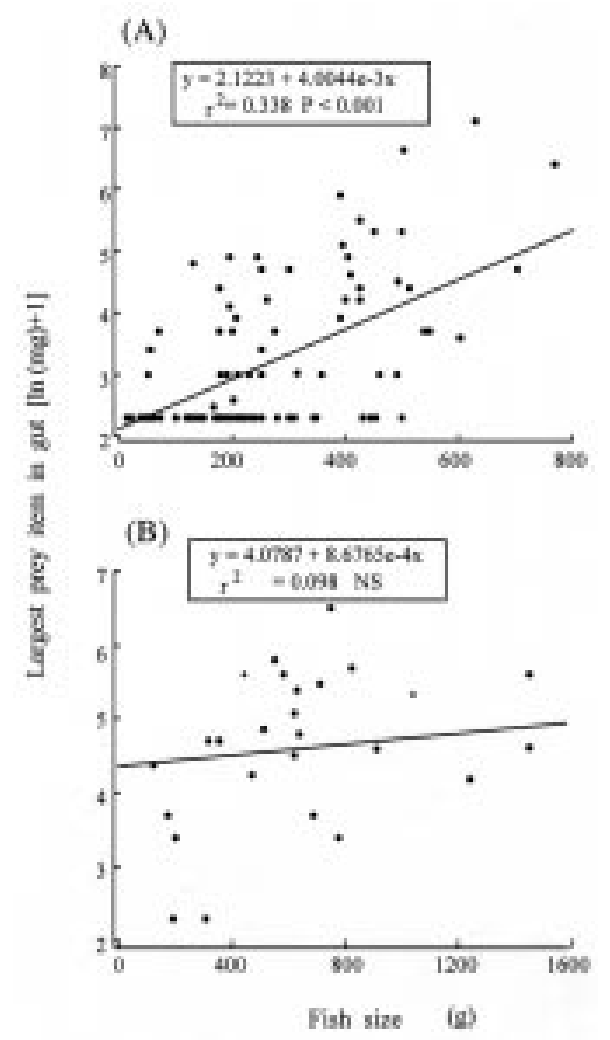

Fig. 5: The relationship between Cheilodactylus variegatus size $(\mathrm{g})$ and the size $(\mathrm{ln}[\mathrm{mg}]+1$ transformed) of the largest prey item in it's gut in (A) NZ and (B) CZ; NS = no significant differences.

La relación entre el tamaño de Cheilodactylus variegatus (g) y el tamaño (ln $[\mathrm{mg}]+1$ transformado) del mayor item presa encontrado en su estómago en (A) NZ y (B) CZ; NS $=$ no existen diferencias significativas. 
by considering the influence of the kind and amount of food available. All of our dietary analyses showed that juvenile individuals were limited to food sources of reduced variety and size $(95 \%$ of the diet, expressed as biomass corresponds to amphipods of small size, see Fig. 5). Moreover, juveniles with proportionally smaller mouth apparatus exploit this resource while using a sucking (picking) technique. This strategy is observed in other species under comparable conditions where body size of the predator is related with changes in quality and also prey size (Laur \& Ebelin 1983, Schmitt \& Holbrook 1984a, 1984b). The presence of understory algae, and the amphipods associated with them, along the bathymetric gradient of the NZ would allow the distribution of juvenile $C$. variegatus along the whole subtidal range considered (Fig. 3). In the CZ, in contrast, the subtidal environment does not offer those conditions in such a clear way, however, intertidal pools where the diversity and abundance of foliose and turf forming algae are high, the associated invertebrates are abundant and provide a significant trophic resource. These intertidal pools were the only environments within the central littoral of Chile where juveniles of C.variegatus have been found and where the diet corresponds to small crustaceans (Varas \& Ojeda 1990). Similarly, the distribution and abundance of reef fishes along the South Atlantic Bight have also been showed to be influenced by variations in algal structure of smaller seaweeds such as Sargassum filipendula (Levin \& Hay 1996). These authors found that both the presence and higher density of this alga increased the density and diversity of small-sized fish.

Although the trophic spectrum of $C$. variegatus is wide ( 80 prey items), few of the groups were preferentially selected and then only in the $\mathrm{CZ}$ (Table 4). The availability of amphipods (a major prey item) in the NZ was very high. Therefore, this trophic resource is probably not limiting and there was no evidence of significant selection (Table 4). The pattern of significantly higher amounts of amphipods forming the bulk of the diet was especially important for small fish in the $\mathrm{CZ}$ but of equal importance along the whole ontogeny in the NZ (Fig. 4). This differential pattern of food size during ontogeny suggests that $C$. variegatus selectively seeks prey of smaller average size if they are available (Schmitt \& Holbrook 1984a, 1984b). According to Griffith's (1980) classification, $C$. variegatus in the $\mathrm{NZ}$ would be a searcher that seeks comparatively smaller prey and is also able to consume larger prey as it grows (Fig. 5A). For the $\mathrm{CZ}$ however, the average size of the prey were larger along the ontogeny (Fig. 5B). A similar trophic behavior has also been documented for
Cheilodactylus spectabilis in northern New Zealand, where this species also feeds upon a large suite of invertebrates associated with benthic turf and foliose algae (McCormick 1998). Moreover and similar to our findings, juveniles of $C$. spectabilis mainly consumed gammarid amphipods while adults prey on larger items such as ophiuroids (McCormick 1998).

If the overall average diversity of the diet is considered for both zones (NZ: $\mathrm{H}=0.23 \pm 0.02$, $\mathrm{CZ}: \mathrm{H}=0.33 \pm 0.04)$, the result of greater diversity in the $\mathrm{CZ}$ agrees with what can be predicted by our results. This suggests that, given a lower abundance of amphipods in any environment, $C$. variegatus will show an alternate behavior toward prey of lesser energetic content (Murdoch 1969). This pattern appears to be in contrast with what was observed in the NZ where the very high abundance of amphipods in the environment would support the presence of a large population of fish distributed over the whole bathymetric gradient.

The present work reveals some previously unknown features about the natural history and the ecological role played by $C$. variegatus in shallow subtidal environments of the Chilean temperate (CZ) and subtropical (NZ) littoral. Some ecological aspects were compared between two widely separated populations of $C$. variegatus and the results showed that both trophic behavior and use of space (bathymetric distribution) were factors susceptible to change depending upon local conditions. The patterns described agree to a great extent with those observed for other species with comparable trophic behavior inhabiting similar environments (Werner \& Hall 1976, Leum \& Choat 1980, Werner \& Mittelbach 1981, Werner et al. 1983, Schmitt \& Holbrook 1984a, 1984b, McCormick 1998). Although an empirical approach, especially in relation to prey selectivity at different ontogenetic stages would be interesting, the regional comparison presented here shows how different environmental conditions produce important changes in trophic behavior, distribution, abundance and also phenotype (average smaller body size in the NZ) of $C$. variegatus. In particular the differences shown in algal species composition and density, hence associated invertebrates, strongly suggest how distribution and abundance of trophic resources may affect the distribution and abundance of predators.

\section{ACKNOWLEDGMENTS}

We thank G. Benavides, J.M. Farina, W. Cáceres, L. Fuentes, P. Camus, E. Varas and P. Zavala for important assistance in the field. Eduardo Varas, 
W. Cáceres, R. Steneck, R. Wahle, P. Voorhees, M.G. Nascimento, J. McCleave and T. Miller read, and made valuable improvements to this paper. This research was supported by FONDECYT (3990032) to A.T.P., and FONDECYT grants (0349-89 and 0753-91) to F.P.O.

\section{LITERATURE CITED}

ANDERSON TW (1994) Role of macroalgal structure in the dsitribition and abundance of a temperate reef fish. Marine Ecology Progress Series 113: 279-290.

ANGEL A \& FP OJEDA (2001) Structure and trophic organization of subtidal fish assemblages on the northern Chilean coast: the effect of habitat complexity. Marine Ecology Progress Series 217: 81-91.

BODKIN JL (1988) Effects of kelp removal on associated fish assemblages in central California. Journal of Experimental Marine Biology and Ecology 117: 227 238.

CÁCERES CW, AG BENAVIDES \& FP OJEDA (1993) Ecología trófica del pez herbívoro Aplodactylus punctatus (Pisces: Aplodactylidae) en la costa centronorte de Chile. Revista Chilena de Historia Natural 66: 185-194.

CÁCERES CW, LS FUENTES \& FP OJEDA (1994). Optimal feeding strategy of the temperate herbivorous fish Aplodactylus punctatus: the effects of food availability on digestive and reproductive patterns. Oecologia 99: 118-123.

CAMUS AP \& FP OJEDA (1992) Scale-dependent variability of density estimates and morphometric relationships in subtidal stands of the kelp Lessonia trabeculata in northern and central Chile. Marine Ecology Progress Series 90: 193-200.

CARR MH (1989) Effects of macroalgal assemblages on the recruitment of temperate zone reef fishes. Journal of Experimental Marine Biology and Ecology 126: 59-76.

CHIRICHIGNO N (1974) Clave para identificar los peces marinos del Perú. Instituto del Mar del Perú, Informe No. 44, Callao, Perú. 387 pp.

CHOAT JH \& DR BELLWOOD (1991) Reef fish: their ecology and evolution. In: Sale PF (ed) The ecology of fishes on coral reefs: 39-66. Academic Press, San Diego, California.

CHOAT JH \& AM AYLING (1987) The relationship between habitat structure and fish faunas on New Zealand reefs. Journal of Experimental Marine Biology and Ecology 110: 257-284.

CHOAT JH (1982) Fish feeding and the structure of benthic communities in temperate waters. Annual Review of Ecology and Systematics 13: 423-449.

CHOAT JH \& DR BELLWOOD (1991) Reef fish: their ecology and evolution. In: Sale PF (ed) The ecology of fishes on coral reefs: 39-66. Academic Press, San Diego, California.

DAYTON PK (1985a) The structure and regulation of some South American kelp communities. Ecological Monographs 55: 447-468.
DAYTON PK (1985b) Ecology of kelp communities. Annual Review of Ecology and Systematics 16: 215 245.

DeMARTINI EE \& DA ROBERTS (1990) Effects of giant kelp (Macrocystis) on the density and abundance of fishes in a cobble-bottom kelp forest. Bulletin of Marine Science 41: 287-300.

EBELING AW \& MA HIXON (1991) Tropical and temperate reef fish: comparison of community structures In: Sale PF (ed) The ecology of fishes on coral reefs: 509-563. Academic Press, San Diego, California.

EDGAR GJ (1983a) The ecology of south-east Tasmanian phytal animal communities. I. Spatial organization on a local scale. Journal of Experimental Marine Biology and Ecology 70: 129-157.

EDGAR GJ (1983b) The ecology of south-east Tasmanian phytal animal communities. II. Seasonal change in plant and animal populations. Journal of Experimental Marine Biology and Ecology 70: 159-179.

GOTCEITAS V (1990a) Variation in plant stem density and its effects on foraging success of juvenile bluegill sunfish. Environmental Biology of Fishes 27: 6370.

GOTCEITAS V (1990b) Foraging and predator avoidance: a test of a patch choice model with juvenile bluegill sunfish. Oecologia 83: 346-351.

GRIFFITHS D (1980) Foraging cost and relative prey size. American Naturalist 116: 743-752.

HACKER SD \& RS STENECK (1990) Habitat architecture and the abundance and body-size-dependent habitat selection of a phytal amphipod. Ecology 71:2269. 2285.

HAY ME, JE DUFFY \& W FENICAL (1990) Host-plant specialization decreases predation on a marine amphipod: an herbivore in plant's clothing. Ecology 71: 733-743.

HOLBROOK SJ \& RJ SCHMITT (1984) Experimental analysis of patch selection by foraging black surfperch (Embiotoca jacksoni Agazzi). Journal of Experimental Marine Biology and Ecology 79: 39-64.

HOLBROOK SJ \& RJ SCHMITT (1989) Resource overlap, prey dynamics, and the strength of competition. Ecology 70: 1943-1953.

HOLBROOK SJ, MH CARR, RJ SCHMITT \& JA COYER (1990) Effect of giant kelp on local abundance of reef fishes: the importance of ontogenetic resource requirements. Bulletin of Marine Science 47: 104-114.

LARSON RJ \& EE DeMARTINI (1984) Abundance and vertical distribution of fishes in a cobble-bottom kelp forest off San Onofre, California. Fishery Bulletin (United States) 82: 37-53.

LAUR DR \& AW EBELING (1983) Predatory-prey relationships in surfperches. Environmental Biology of Fishes 8: 217-229.

LEUM LL \& JH CHOAT (1980) Density and distribution patterns of the temperate marine fish Cheilodactylus spectabilis (Cheilodactylidae) in a reef environment. Marine Biology 57: 327-337.

LEVIN PS \& M HAY (1996) Responses of temperate reef fishes to alterations in algal structure and species composition. Marine Ecology Progress Series 134: 37-271. 
LUCKHURST BE \& K LUCKHURST (1978a) Analysis of the influence of substrate variables on coral reef fish communities. Marine Biology 49: 317-323.

LUCKHURST BE \& K LUCKHURST (1978b) Diurnal space utilization in coral reef fish communities. Marine Biology 49: 325-332.

McCORMICK ML (1998) Ontogeny of diet shifts by a microcarnivorous fish, Cheilodactylus spectabilis: relationship between feeding mechanics, microhabitat selection and growth. Marine Biology 132: 9-20

McKenZIE JD \& PG MOORE (1981) The microdistribution of animals associated with the bulbous holdfasts of Saccorhiza polyschides (Phaeophyta). Ophelia 20: 201-213.

MIRANDA O (1967) Enumeración de la comunidad de peces, mediante la red de tres telas en hábitat rocoso. Biología Pesquera (Chile) 2: 3-49.

MORENO CA \& HF JARA (1984) Ecological studies on fish fauna associated with Macrocystis pyrifera belts in the south of Fueguian islands, Chile. Marine Ecology Progress Series 15: 99-107.

MORENO CA, WE DUARTE \& JH ZAMORANO (1979) Variación latitudinal del número de especies de peces sublitoral rocoso: una explicación ecológica. Archivos de Biología y Medicina Experimentales (Chile) 12: 169-178.

MURDOCH WW (1969) Switching in general predators: experiments on predator specificity and stability of prey populations. Ecological Monographs 39: 335354.

NIELSEN SG (1963) On the development of Cheilodactylus variegatus Valenciennes 1833 (Cheilodactylidae). Copeia 1963: 528-533.

NÚÑEZ LN \& JA VÁSQUEZ (1987) Observaciones tróficas y de distribución espacial de peces asociados a un bosque submareal de Lessonia trabeculata. Estudios Oceanológicos (Chile) 6: 79-85.

OJEDA FP \& JH DEARBORN (1990) Diversity, abundance and spatial distribution of fish and crustaceans in the rocky subtidal zone of the Gulf of Maine. Fishery Bulletin (United States) 88: 403-410.

PALMA AT, RA WAHLE \& RS STENECK (1998) Different early post-settlement strategies between American lobsters Homarus americanus and rock crabs Cancer irroratus in the Gulf of Maine. Marine Ecology Progress Series 162: 215-225.

PEARRE S (1982) Estimating prey preference by predator: uses of various indices, and a proposal of of another based on Chi-square. Canadian Journal of Fisheries and Aquatic Sciences 39: 914-923.

PINKAS L, MS OLIPHANT \& ILK IVERSON (1971) Food habits of the albacore, bluefin tuna, and bonito in California waters. California Fish and Game, Fishery Bulletin 152: 1-105.

PRINGLE JD (1984) Efficiency estimates for various quadrat sizes used in benthic sampling. Canadian Journal of Fisheries and Aquatic Sciences 41: 14851489.
RICHARDS LJ (1986) Depth and habitat distribution of three species of rockfish (Sebastes) in British Columbia: observations from the submersible Pisces IV. Environmental Biology of Fishes 17: 13-21.

SCHMITT JR \& SJ HOLBROOK (1984a) Gape-limitation, foraging tactics and prey size selectivity of two microcarnivorous species of fish. Oecologia 63: 612.

SCHMITT JR \& SJ HOLBROOK (1984b) Ontogeny of prey selection by black surfperch Embiotoca jacksoni (Pisces: Embiotocidae): two roles of fish morphology, foraging behavior and patch selection. Marine Ecology Progress Series 18: 225-239.

SEDBERRY GR \& RF VAN DOLAH (1984) Demersal fish assemblages associated with hard bottom habitat in the South Atlantic Bight of the U.S.A. Environmental Biology of Fishes 11: 241-258.

SIEGEL S \& NJ CASTELLAN (1988) Nonparametric statistics for the behavioral sciences. Second edition. McGraw-Hill Book Company, New York, New York. 399 pp.

SOKAL RR \& FJ ROHLF (1981) Biometry. Second edition. W.H. Freeman, San Francisco, California 859 pp.

SOTO E (1985) Antecedentes biológicos y análisis de los contenidos gástricos de Sebastes capensis (Gmellin, 1788) y Cheilodactylus variegatus (Valenciennes 1833), recolectados en caleta Errázuriz (Lat: $23^{\circ} 26^{\circ}$ S). Seminario de Título Profesional, Universidad de Antofagasta, Antofagasta, Chile. 67 pp.

STEPIEN CA (1986) Life history and larval development of the giant kelpfish, Heterostichus rostratus Girard, 1854. Fishery Bulletin (United States) 84: 809-826.

STONER A \& RJ LIVINGSTON (1980) Distributional ecology and food habits of the banded blenny Parachinus fasciatus (Clinidae): a resident in a mobile habitat. Marine Biology 56: 239-246.

VARAS E \& FP OJEDA (1990) Intertidal fish assemblages of the central Chilean coast: diversity, abundance and trophic patterns. Revista de Biología Marina (Chile) 25: 59-70.

VARGAS L \& G PEQUEÑO (in press) El "bilagai" Cheilodactylus variegatus Valenciennes, 1833, en la bahía Metri, Chile (Osteichthyes: Cheilodatylidae)", Investigaciones Marinas (Chile).

WERNER EE \& DJ HALL (1976) Niche shifts in sunfishes: experimental evidence and significance. Science 191: 404-406.

WERNER EE \& GG MITTELBACH (1981) Optimal foraging: field test of diet choice and habitat switching. American Zoologist 21: 813-829.

WERNER EE, JF GILLIAM, DJ HALL \& GG MITTELBACH (1983) An experimental test of the effects of predation risk on habitat use in fish. Ecology 64: 1540-1548.

ZAR JH (1999) Biostatistical analysis. Prentice-Hall, Upper Saddle River, New Jersey. 663 pp. 